\title{
c-fos Expression in Brainstem Premotor Interneurons during Cholinergically Induced Active Sleep in the Cat
}

\author{
Francisco R. Morales, Sharon Sampogna, Jack Yamuy, and Michael H. Chase \\ Department of Physiology and the Brain Research Institute, University of California Los Angeles, Los Angeles, \\ California 90024
}

The present study was undertaken to identify trigeminal premotor interneurons that become activated during carbacholinduced active sleep (c-AS). Their identification is a critical step in determining the neural circuits responsible for the atonia of active sleep. Accordingly, the retrograde tracer cholera toxin subunit $B(C T b)$ was injected into the trigeminal motor nuclei complex to label trigeminal interneurons. To identify retrogradelabeled activated neurons, immunocytochemical techniques, designed to label the Fos protein, were used. Double-labeled (i.e., $\mathrm{CTb}^{+}, \mathrm{Fos}^{+}$) neurons were found exclusively in the ventral portion of the medullary reticular formation, medial to the facial motor nucleus and lateral to the inferior olive. This region, which encompasses the ventral portion of the nucleus reticularis gi- gantocellularis and the nucleus magnocellularis, corresponds to the rostral portion of the classic inhibitory region of Magoun and Rhines (1946). This region contained a mean of $606 \pm 41.5$ ipsilateral and $90 \pm 32.0$ contralateral, CTb-labeled neurons. These cells were of medium-size with an average soma diameter of 20-35 $\mu \mathrm{m}$. Approximately $55 \%$ of the retrogradely labeled cells expressed $c$-fos during a prolonged episode of c-AS. We propose that these neurons are the interneurons responsible for the nonreciprocal postsynaptic inhibition of trigeminal motoneurons that occurs during active sleep.

Key words: REM sleep; motor control; brainstem; trigeminal; immunohistochemistry; cholera toxin; Fos
The state of active sleep [AS; also called rapid-eye-movement (REM) sleep] is a complex mosaic of incompletely understood physiological processes (for review, see Siegel, 1989; Steriade and McCarley, 1990; Jones, 1991). A key consistent component of this state is the suppression of somatic muscle activity (Dement, 1958; Jouvet et al., 1959) that is dependent on postsynaptic inhibitory processes acting on somatic motoneurons (Pompeiano, 1967; Chandler et al., 1980; Morales and Chase, 1981). As originally described, the suppression of muscle tone was thought to involve mostly antigravity musculature; hence, this component of AS received the designation of postural atonia. However, it is now clear that the postsynaptic inhibitory processes that occur during AS control motoneurons throughout the neuroaxis (Chandler et al., 1980; Glenn and Dement, 1981; Morales and Chase, 1981; Morales et al., 1987a), including those that do not participate in postural or antigravity functions such as jaw opener or hypoglossal motoneurons (Pedroarena et al., 1994; Fung et al., 1998).

Motoneuron inhibition during AS is likely produced by an as yet unidentified population of glycinergic premotor interneurons (Chase et al., 1989; Soja et al., 1990). We believe that it is important to identify these neurons as a first step in unraveling the circuitry responsible for the suppression of motor activity that occurs during AS. Accordingly, in the present study, we focused on the functional innervation of the trigeminal motor pool. Two

Received June 2, 1999; revised Aug. 12, 1999; accepted Aug. 16, 1999.

This work was supported by the United States Public Health Service Grants NS 23426, NS 09999, and MH 43362. We are grateful to P. H. Luppi who contributed to the development of $\mathrm{CTb}$ immunostaining in our laboratory. F. López-Rodríguez and K. Kohlmeier participated in the initial experiments of this project. Inés Pose contributed with the artwork. We thank Gerardo Morales for his excellent technical assistance.

Correspondence should be addressed to Dr. Francisco Morales, Department of Physiology, University of California Los Angeles School of Medicine, Los Angeles, CA 90095. E-mail: fmorales@ucla.edu.

Copyright (C) 1999 Society for Neuroscience 0270-6474/99/199508-11\$05.00/0 immunohistochemical techniques were combined to identify which population, of the many groups of trigeminal premotor interneurons, becomes activated during an AS-like state induced by pontine injections of carbachol (c-AS) (Baghdoyan et al., 1987; Vanni-Mercier et al., 1989). The first immunohistochemical technique consisted of labeling premotor neurons after cholera toxin subunit $\mathrm{B}(\mathrm{CTb})$ injections within the trigeminal motor nucleus (mV) complex (Fort et al., 1990). The second immunohistochemical technique involved the detection of the nuclear protein Fos, which is synthesized during certain forms of neuronal activation as a consequence of intraneuronal metabolic changes (Dragunow and Faull, 1989; Menétrey et al., 1989; Luckman et al., 1994; for recent review, see Herrera and Robertson, 1996; Chaudhuri, 1997). Thus, we sought to determine the cells that project to the trigeminal motor pool that are activated during c-AS.

Premotor trigeminal interneurons that expressed $c$-fos after a prolonged episode of c-AS $\left(\mathrm{CTb}^{+}, \mathrm{Fos}^{+}\right.$cells) were located in the nucleus reticularis gigantocellularis (NRGc) and in the nucleus magnocellularis (Mc). Colocalized with these trigeminal premotor interneurons in these nuclei and extending caudally into the nucleus paramedianus reticularis (nPR), a significant number of $\mathrm{Fos}^{+}$cells during c-AS were found. These three nuclei (NRGc, Mc, and nPR) are part of the "inhibitory region of Magoun and Rhines" (see Magoun and Rhines, 1946; Jankowska et al., 1968). Therefore, we propose that these nuclei contain premotor inhibitory interneurons, which control motoneuron activity during the state of active sleep.

Parts of this paper have been published previously (Morales et al., 1996).

\section{MATERIALS AND METHODS}

Fourteen adult cats of both sexes, weighing 3.0-3.5 kg, were used in the present study. Eleven animals were studied after prolonged c-AS (exper- 
imental animals); three cats in which saline was injected into the reticularis pontis oralis nucleus (NPO) were used as controls (control animals).

Initial surgical procedures. All experimental procedures were conducted in accordance with the Guide for the Care and Use of Laboratory Animals (7th edition) and approved by the Chancellor's Animal Research Committee of the University of California Los Angeles office for the protection of research subjects. Before anesthesia, the animals were premedicated with atropine $(0.4 \mathrm{mg} / \mathrm{kg}, \mathrm{i} . \mathrm{m}$.) and Xylazine $(2 \mathrm{mg} / \mathrm{kg}$, i.m.). Anesthesia was first induced with Ketamine $(15 \mathrm{mg} / \mathrm{kg}$, i.m.) and maintained with a gas mixture of halothane in oxygen (2-3\%).

The head of the cat was positioned in a heavy-duty stereotaxic frame, and the calvarium was exposed. Stainless steel screw electrodes were threaded into the frontal and parietal bones and into the orbital portion of the frontal bone to record EEG and electro-olfactogram (EOG) waves, respectively. A Winchester plug that was connected to these electrodes and a chronic head-restraining device were bonded to the calvarium with acrylic cement. A hole $3.0-4.0 \mathrm{~mm}$ in diameter was drilled in the calvarium overlying the cerebellar cortex; it was then covered with bone wax. This hole provided later access (1) to the trigeminal motor nuclei for injection of CTb and (2) to the NPO for the injection of carbachol. During the recovery period from surgery, an analgesic (Buprenex, $0.01 \mathrm{mg} / \mathrm{kg}$, i.m.) was administered. An antibiotic (Cephazolin) was administered parenterally for $4 \mathrm{~d}$. The wound margins were regularly cleaned and covered with antibiotic ointment (Fougera). The animals were allowed to recover from these surgical procedures for 2 weeks. After this period, they were adapted to the head-restraining device until they exhibited episodes of naturally occurring sleep.

Micropipette and microelectrode assembly for injection of substances and for recording masseter antidromic field potentials. To inject CTb within the trigeminal motor nucleus, a three-barrel assembly, consisting of a carbon fiber-recording microelectrode and two side barrels containing CTb, was lowered into the motor pool. CTb was injected by iontophoresis $(2 \mu \mathrm{A}$ positive current pulses, $7 \mathrm{sec}$ on and $7 \mathrm{sec}$ off, for $20 \mathrm{~min}$ in each barrel) where the masseteric antidromic field potential was largest $[4-5 \mathrm{mV}$ (Castillo et al., 1991)]. The cats were allowed to survive for 10-14 d before the final experimental procedure.

Microinjections of carbachol were performed by iontophoresis using a five-barrel assembly (López-Rodríguez et al., 1994). The tips of the micropipettes were broken to a total diameter of 40-50 $\mu \mathrm{m}(10 \mu \mathrm{m}$ tip diameter for each micropipette). Four pipettes of the assembly were filled with carbachol dissolved in saline $(200 \mathrm{~mm})$; one was filled with $2 \mathrm{M} \mathrm{NaCl}$ for automatic current balancing. The same currents used for carbachol iontophoresis were applied in control animals; in this case the barrels were filled with saline.

One day before the final experiment, each animal was briefly anesthetized with halothane, the bone wax plug covering the access hole in the calvarium was removed, and the underlying dura matter was cut. On the day of the final experiment, EEG, EMG, and EOG activity was recorded. The micropipette assembly was lowered through the access hole to inject carbachol at the following stereotaxic coordinates: posterior, 2.0; lateral, 1.3; and vertical, 3.5 (Berman, 1968). Eleven cats were injected with carbachol. Total currents of 300-500 nA applied for 1-3 min were usually required to induce c-AS. These injections were occasionally repeated to maintain the state for a total duration of $2 \mathrm{hr}$. The experimental animals remained in c-AS $90 \%$ of the recording time. In three control cats the same procedures were followed except that saline was substituted for carbachol. During the recording session, these control animals remained in a state of quiet wakefulness with intermittent episodes of quiet (N-REM) sleep except for one cat in which a 3 min episode of "spontaneous" AS (2.5\% of the total recording session) took place.

After the $2 \mathrm{hr}$ recording session, the animals were given an overdose of sodium pentobarbital $(60 \mathrm{mg} / \mathrm{kg}$, i.p.) and perfused transcardiacally with 11 of saline followed by 2.51 of a solution of $4 \%$ paraformaldehyde, $15 \%$ saturated picric acid, and $0.25 \%$ glutaraldehyde in $0.1 \mathrm{M}$ phosphate buffer at $\mathrm{pH}$ 7.4. The brainstem was removed and immersed for a $24 \mathrm{hr}$ post-fixation period in a solution consisting of $2 \%$ paraformaldehyde and $15 \%$ saturated picric acid in $0.1 \mathrm{M}$ phosphate buffer at $\mathrm{pH} 7.4$. After post-fixation, the tissue was kept in a solution of sucrose $(30 \%)$ in $0.1 \mathrm{M}$ phosphate buffer at $\mathrm{pH}$ 7.4.

Forty-eight to seventy-two hours later, the brainstem was frozen and cut in $15-\mu \mathrm{m}$-thick sections using a Reichert-Jung cryostat. Each section was placed in one well of a 36-well tray containing a PBS-buffered solution. The first section obtained was placed in the first well of the tray, and consecutive sections were placed in the remaining wells in serial order. Section number 37 was placed in well 1, and the procedure was repeated until the entire brainstem was sectioned. Each well contained a sample of the entire brainstem with each section in the well separated by $540 \mu \mathrm{m}$ (i.e., $15 \mu \mathrm{m} \times 36$ ). By the use of this procedure, neighbor wells contained pairs of adjacent sections. The tissue was stored in $0.1 \mathrm{M}$ PBS containing $0.3 \%$ Triton $\mathrm{X}-100$ and $0.1 \%$ sodium azide. The brainstems were cut in a coronal plane with the exception of two experimental cats whose brainstems were sectioned horizontally.

Immunocytochemistry. Immunohistochemical detection of $\mathrm{CTb}$ was performed by sequential incubations of free-floating sections. Sections were first incubated in goat antiserum to CTb (List Biologic, Campbell, CA) at a dilution of 1:40,000 in PBS, $0.25 \%$ Triton X-100, and $0.1 \% \mathrm{Na}$ azide (PBST-AZ), $\mathrm{pH} 7.4$, at $4^{\circ} \mathrm{C}$ with gentle agitation for $72 \mathrm{hr}$ or at a 1:20,000 dilution overnight at room temperature. The sections were rinsed over a $30 \mathrm{~min}$ period and placed for $90 \mathrm{~min}$ at room temperature in biotinylated donkey anti-goat serum (The Jackson Laboratory, Bar Harbor, ME) diluted 1:2000 with PBST. After rinsing for $30 \mathrm{~min}$, the sections were incubated in standard ABC (Vector Laboratories, Burlingame, CA) for $90 \mathrm{~min}$ at room temperature at a dilution of 1:400. The tissues were then rinsed for a total of $30 \mathrm{~min}$ followed by the nickel ammonium sulfate-enhanced DAB method consisting of immersion in $0.6 \%$ nickel ammonium sulfate, $0.2 \% \mathrm{DAB}$, and $0.05 \%$ hydrogen peroxide in $50 \mathrm{ml}$ of $50 \mathrm{~mm}$ Tris buffer, $\mathrm{pH}=7.6$, for $15-30 \mathrm{~min}$. The reaction was then terminated by several rinses in PBST.

These same sections were then processed for Fos immunostaining using a polyclonal rabbit antibody (Fos Ab5; Oncogene Research Products/Calbiochem, La Jolla, CA). The free-floating sections were incubated overnight in this antiserum at a dilution of 1:20,000 in PBST-AZ. The sections were then rinsed in PBST for $30 \mathrm{~min}$ and incubated for 90 min in biotinylated donkey anti-rabbit $\operatorname{IgG}$ diluted 1:300 and containing $1.5 \%$ normal donkey serum. After rinsing for $30 \mathrm{~min}$, the sections were incubated for $90 \mathrm{~min}$ in the $\mathrm{ABC}$ at a dilution of 1:200. The tissues were then rinsed, and the peroxidase activity was visualized by the DAB method described above (omitting nickel enhancement). After several rinses of PBST, the sections were mounted onto Superfrost Plus slides from a PBST diluted to $0.01 \%$.

We began the examination of the neurotransmitter phenotype(s) of the population of $\mathrm{Ctb}^{+}, \mathrm{Fos}^{+}$ventral medullary neurons by first assaying the distribution pattern of glycine-like immunoreactivity. (This work is being developed in collaboration with Claire Rampon and Pierre Luppi from the Laboratoire of Médecine Experimental, Lyon, France.) Two different rabbit antibodies raised against glycine-conjugated proteins with glutaraldehyde (one antibody was obtained from Chemicon, Temecula, CA; the other was from Interchim) were used. Sections processed for detection of $\mathrm{CTb}$ or Fos were then processed for detection of glycine-like immunoreactivity. For a full description of the glycine-immunostaining technique, see Rampon et al. (1996a).

Data analysis. Histological sections were examined using an Olympus BX60 microscope (Olympus Optical, Tokyo, Japan). First, the extent of the $\mathrm{CTb}$ injection was examined in several sections for each cat. The deposits of $\mathrm{CTb}$ consisted of a circular central zone of dark reaction product [mean diameter, $0.9 \pm 0.08 \mathrm{~mm}( \pm$ SEM $)$ ] surrounded by a lighter-stained zone, probably caused by the extracellular diffusion of $\mathrm{CTb}$ to adjacent regions (Fig. 1).

Diagrams of $\mathrm{CTb}$ deposits in different animals are shown in Figure 2. Figure $2 A$ is an example in which the deposit of $\mathrm{CTb}$ included a significant portion of $\mathrm{mV}$ with little diff usion to adjacent structures. This localization of the injection to the $\mathrm{mV}$ was accomplished in four experimental (another example is shown in Fig. 1) and two control cats. In Figure $2 B$ we illustrate the example of an experimental cat with two deposit sites within the $\mathrm{mV}$. In two experimental cats the injection site was dorsal to the $\mathrm{mV}$ (Fig. $2 C$ ). In three cats there were two deposits of CTb (Fig. 2D), which probably occurred as a result of the displacement of the tip of one of the CTb-carrying micropipettes of the injection assembly during the descent through an estimated $14 \mathrm{~mm}$ of cerebellum and brainstem tissue. In two experimental animals the deposit of $\mathrm{CTb}$ was mainly within the $\mathrm{mV}$, but it also extended beyond the nucleus. In the two remaining cats, their brainstems were sectioned horizontally. In one of these animals the $\mathrm{CTb}$ deposit was within the $\mathrm{mV}$, whereas in the other the injection was posterior to this nucleus.

The distribution of CTb-labeled neurons was first assessed using drawings of the histological sections made with the aid of a camera lucida attachment. Pretrigeminal, AS-“activated" neurons were found exclusively within the ventromedial medullary reticular formation; subsequent quantitative analyses were performed on the cells of this region. The rostrocaudal extension of this region was $1.2 \mathrm{~mm}$ from the posterior pole 

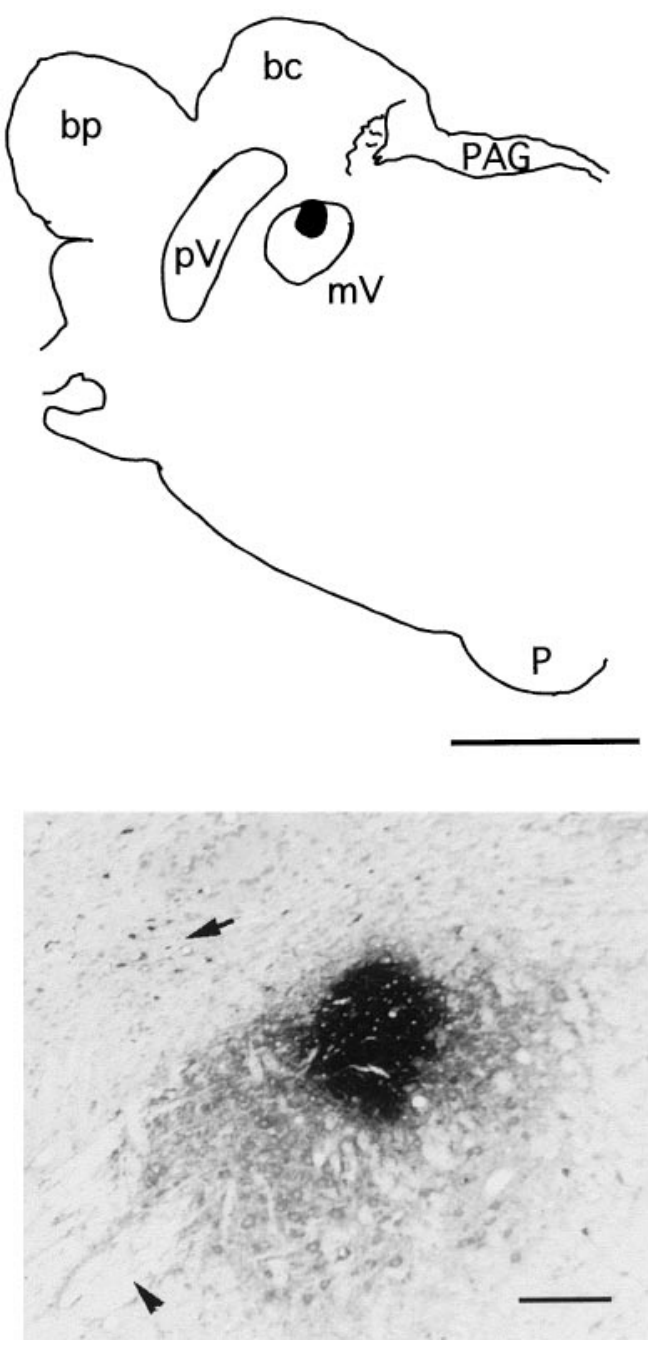

Figure 1. Top, Diagram is of a coronal section of the pons of an experimental animal. The dark area represents a deposit of $\mathrm{CTb}$ in the trigeminal motor nucleus. Bottom, The photomicrograph is of this deposit. The arrow in the photomicrograph points to a group of $\mathrm{CTb}$ retrogradely labeled neurons in the sensory principal nucleus of the trigeminal complex. The arrowhead points to fiber bundles of the trigeminal nerve. Scale bars: Top, $0.5 \mathrm{~mm}$; Bottom, $3 \mathrm{~mm}$. $b c$, Brachium conjunctivum; $b p$, brachium pontis; $m V$, trigeminal motor nucleus; $p$, pyramid; $P A G$, periaqueductal gray; $p V$, sensory principal trigeminal nucleus.

of the facial nucleus to the anterior portion of the inferior olive; its mean coronal area was $2.5 \mathrm{~mm}^{2}$.

To estimate the number of retrogradely labeled neurons, the stereological dissector method, as described by Coggeshall (1992) and Coggeshall and Lekan (1996), was used (see also Saper, 1996). This method requires an estimation of the volume occupied by the region under study (volume reference or $V_{\text {ref }}$ ) and an estimation of the "density" $\left(N_{d}\right)$, in this case, of the $\mathrm{CTb}$-labeled neurons in histological samples of the region. $\left[\left(V_{\text {ref }}\right) \cdot\left(N_{d}\right)\right]$ yields an estimate of the number of CTb-labeled cells in the ventral medulla.

$V_{\text {ref }}$ was calculated using the mean area of the region as measured in 10 randomly selected sections. This value was multiplied by the product of section thickness and the total number of sections (80) that would encompass the whole region. $N_{d}$ was estimated using a "physical dissector," i.e., pairs of consecutive serial sections that were examined both at low and high magnifications to identify the neuronal profiles present in one section and not in the other. Each profile was counted as a neuron. Profiles of neurons that were present in two sections were not counted. The volume of the region in each given section was estimated by multiplying its area by section thickness $(15 \mu \mathrm{m})$. The density of CTb-labeled neurons in any given section was determined as the number of profiles divided by the volume of that section. A total of 12 pairs of sections per cat were analyzed using this method.

To estimate soma profile size, a $100 \times$ oil immersion objective lens was used. Stained neurons in which the nucleolus was apparent were photographed, and their major and minor soma diameters were measured and averaged. Photomicrographs for neuronal counting and illustrations were obtained by means of a digital camera attached to the microscope and connected to a microcomputer with Photoshop software.

Reticular formation nomenclature. Our designation of the different regions of the reticular formation is based on the nomenclature used by Taber (1961) and Berman (1968) (see also Yamuy et al., 1993). The boundary between the midbrain and the pons is defined as a coronal plane immediately posterior to the inferior colliculi; the boundary between the pons and the medulla is another plane immediately posterior to the border of the abducens nucleus. The boundary between the medulla and the spinal cord is the decussation of the pyramidal tract. The pons and medulla are subdivided into lateral and medial regions by an imaginary sagittal plane, $3 \mathrm{~mm}$ from the midline, that separates the lateral from the medial aspects of these structures.

The core of the pons and medulla is occupied by the reticular formation. The lateral portion is the parvocellular reticular formation. From caudal to rostral, we examined this region in the following four levels: (1) the parahypoglossal reticular formation in the caudal medulla, (2) the parvocellularis immediately dorsal to the facial nucleus, (3) a region located lateral and dorsal to the motor root of the facial nerve, which in the rat corresponds to the subdivision $\alpha$ of the parvocellularis, and (4) the parvocellularis just caudal to the $\mathrm{mV}$. The medial reticular formation has different subdivisions such as the NPO and the nucleus reticularis pontis caudalis in the pons and the NRGc and Mc in the rostral medulla. NRGc contains the so-called giant cells ( $\sim 60$ up to $100 \mu \mathrm{m}$ in diameter). Mc is devoid of cells of this "giant" size but contains large cells (between 30 and $40 \mu \mathrm{m}$ in diameter). Intermingled with giant and large cells in the medial RF are cells of medium $(20-30 \mu \mathrm{m}$ in diameter) and small (between 15 and $20 \mu \mathrm{m}$ in diameter) size. The most caudal portion of the medullary reticular formation contains the nPR and the lateral reticular nucleus.

\section{RESULTS}

The following description of the populations of premotor trigeminal interneurons is derived from the analyses of the material from cats in which $\mathrm{CTb}$ injections were restricted to the $\mathrm{mV}$, as illustrated in the diagrams of Figures 1 and $2 A$. In Figure 3, we present diagrams of coronal sections of the brainstem of one experimental cat. The CTb injection site is indicated as a black area in Figure 3B. Empty circles represent the location of $\mathrm{Ctb}^{+}$, Fos $^{-}$neurons. Filled circles, all located within the ventromedial medullary reticular formation (Fig. $3 C$ ), represent $\mathrm{CTb}^{+}, \mathrm{Fos}^{+}$ neurons.

The structures that contain trigeminal premotor neurons (i.e., $\mathrm{CTb}^{+}$) are classified into four groups: (1) those related to the trigeminal sensory system, (2) those immediately adjacent to the $\mathrm{mV}$ that are involved in jaw reflexes and movements (see below), (3) those belonging to monoaminergic nuclei, such as the Kolliker-Fuse and raphe nuclei, and (4) those of different subdivisions of the pontine and medullary reticular formation. Our description of the location of CTb-labeled neurons in the cat is in agreement with that of previous publications in which retrograde tracers were injected within the confines of the $\mathrm{mV}$ in rodents and cats (Mizuno et al., 1983; Travers and Norgren, 1983; Landgren et al., 1986; Fort et al., 1990).

The following is a description of trigeminal premotor structures in relation to their neuronal $c$-fos expression after a prolonged episode of c-AS.

\section{CTb-labeled neurons in sensory trigeminal structures}

Numerous CTb-labeled neurons were located in the mesencephalic trigeminal nucleus ( $\mathrm{MeV})$, in the sensory principal nucleus, and in the spinal nucleus of the trigeminal tract. Examples of 

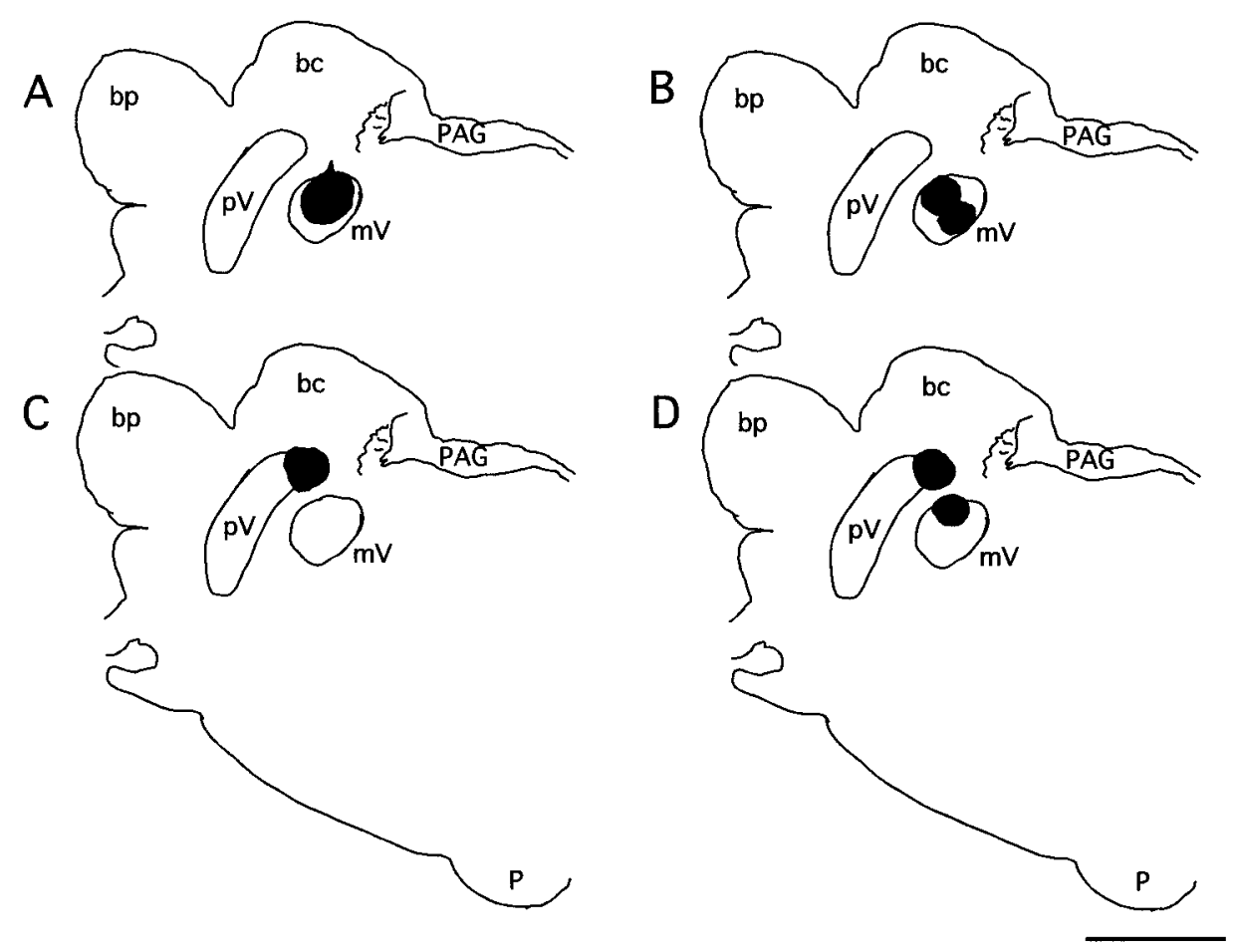

Figure 2. Diagrams of coronal sections of the pons at the level of the trigeminal motor nucleus in four different cats. The dark areas represent the deposit site of $\mathrm{CTb}$ in these animals. $A$, The injection site is relatively large and almost completely within the motor nucleus. $B$, Two injection sites are within the motor nucleus (see Materials and Methods). $C$, The injection was instead located in the dorsal portion of the sensory principal nucleus of the trigeminal complex. $D$, There were two deposits of $\mathrm{CTb}$; one was located dorsal to the $\mathrm{mV}$ within the sensory principal, and the second, more ventral, one was within a portion of the $\mathrm{mV}$. Histological data for the present report were collected from cats with $\mathrm{CTb}$ injection sites such as those presented in $A$ and $B$ (see another example in Fig. 1). Scale bar, 3 mm. $b c$, Brachium conjunctivum; $b p$, brachium pontis; $m V$, trigeminal motor nucleus; $p$, pyramid; $P A G$, periaqueductal gray; $p V$, sensory principal trigeminal nucleus. these cells are shown in Figure $4, A$ and $B$. None of these pretrigeminal neurons expressed $c$-fos during c-AS.

Mesencephalic trigeminal neurons are distributed along a thin ipsilateral band that extends from just anterior to the $\mathrm{mV}$ nucleus to the midportion of the mesencephalon where they are located in the lateral border of the periaqueductal gray. The microphotograph in Figure $4 A$ illustrates a cluster of these neurons. In this photograph, two stained cells are indicated by short arrowhead; in contact with these neurons there are two cells that did not contain the intracellular tracer (long arrows) in spite of the fact that $\mathrm{CTb}$ remained in this animal for 2 weeks before the terminal experiment and that gap junctions between $\mathrm{MeV}$ neurons provide a potential pathway for substances to diffuse from one neuron to another (Liem et al., 1991). On the basis of this evidence, we suggest that gap junctions are not permeable to CTb. Previously, Fort et al. (1990) have discussed the evidence that also indicates that there is no trans-synaptic retrograde transport of the CTb.

\section{Structures adjacent to the $\mathrm{mV}$ that contain trigeminal interneurons}

These structures include the supratrigeminal (SuV) (Lorente de Nó, 1922; Mizuno et al., 1983) and the intertrigeminal nuclei (IntV) (Landgren et al., 1986) and a region that contains a set of commissural neurons located ventromedial to the $\mathrm{mV}$, described by Mizuno et al. (1978). SuV and IntV play an important role in mediating jaw-opening and -closing reflexes (Kidokoro et al., 1968; Luschei and Goldberg, 1981; Lund and Olsson, 1983; Minkels et al., 1995). The function of the commissural neurons is unknown. Numerous $\mathrm{CTb}^{+}$neurons were found in these regions; however, none expressed $c$-fos. (See, for example, the photomicrographs in Fig. 4C,D).

\section{Monoaminergic structures that innervate the $\mathrm{mV}$}

Noradrenergic innervation of trigeminal motor nuclei originates from cells located in the Kolliker-Fuse nucleus (KF) (Fort et al., 1990). Within this structure, we found scattered CTb-labeled cells that did not express $c$-fos. We have reported previously that a small percentage $(\sim 6 \%)$ of the catecholaminergic neurons within the KF express $c$-fos in control conditions and during c-AS (Yamuy et al., 1998). The results of the present study suggest that these neurons do not innervate trigeminal motor pools. $\mathrm{CTb}^{+}$ neurons were observed in the raphe magnus, pallidus, and obscurus; none expressed c-fos during c-AS. The location of these monoaminergic cells is illustrated in the diagrams in Figure 3, A and $D$.

\section{Reticular formation}

\section{Parvocellular reticular formation}

Numerous premotor trigeminal interneurons were found in this region (see Figs. 3, 6, diagrams). None of these cells expressed $c$-fos during c-AS. Examples of $\mathrm{CTb}^{+}, \mathrm{Fos}^{-}$neurons are illustrated in Figure 5. These are significant data because it has been suggested previously that the parvocellular reticular formation was the origin of the inhibitory processes acting on trigeminal motoneurons during AS (Pedroarena et al., 1990; Rampon et al., 1996b). These suggestions are difficult to reconcile with the present data (see Discussion).

\section{Medial pontine reticular formation}

The medial pontine reticular formation did not contain CTblabeled cells. The distribution and characteristics of pontine Fos $^{+}$neurons have been described previously (Yamuy et al., 1993). The present results confirm that the medial pons does not project directly to the trigeminal motor nuclei.

\section{Medial medullary reticular formation}

Numerous $\mathrm{CTb}^{+}$pretrigeminal interneurons were found in the ventromedial medulla (see Figs. 3, 6, diagrams). Examples of these cells are illustrated in the photomicrographs in Figure 6, $A$ and $B$. A mean number of $606 \pm 41.5 \mathrm{CTb}^{+}$neurons were found ipsilateral to the injection site; there were $92 \pm 32$ contralateral 


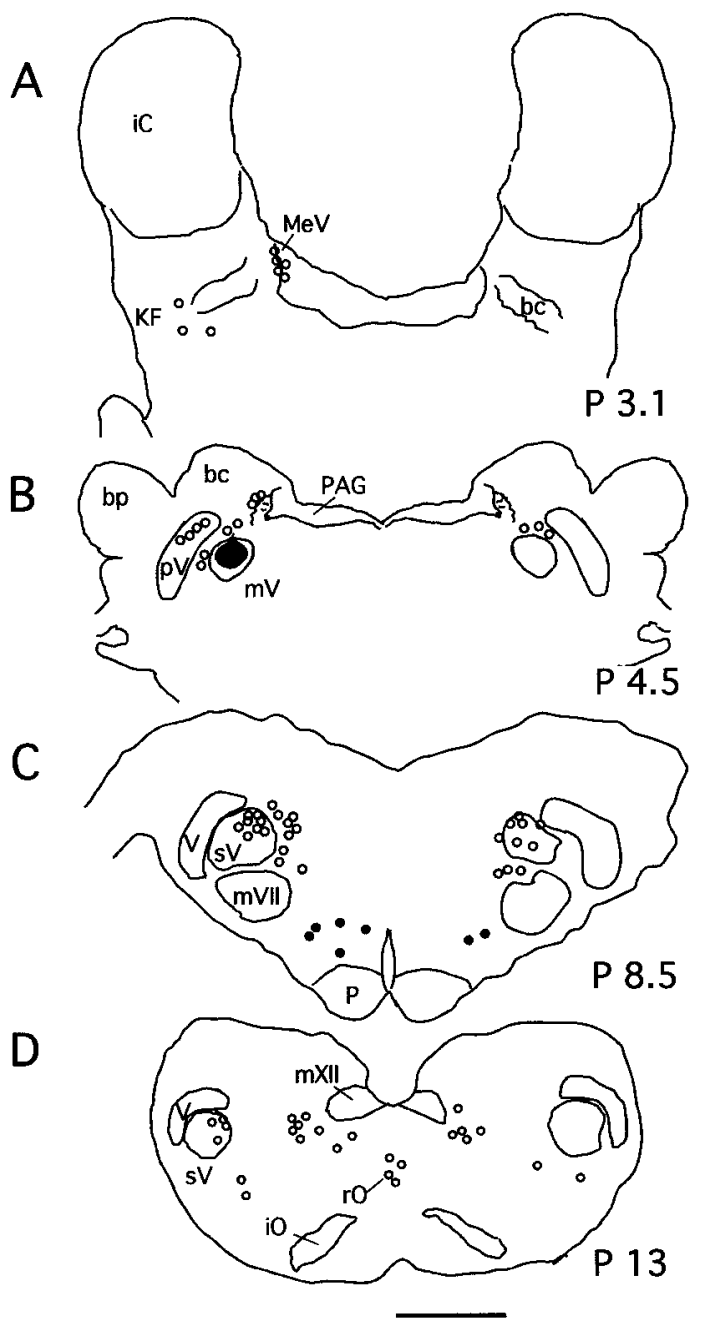

Figure 3. Localization of $\mathrm{CTb}$-labeled trigeminal interneurons at four representative levels $(A-D)$ of the cat brainstem. The diagrams are from an experimental animal from which tissue was obtained immediately after a long episode of c-AS and was processed for both $\mathrm{CTb}$ and Fos protein immunostaining. Empty circles represent $\mathrm{CTb}^{+}, \mathrm{Fos}^{-}$neurons; filled circles represent $\mathrm{CTb}^{+}, \mathrm{Fos}^{+}$neurons, all of which were located within the ventromedial medulla. In $B$, the dark area represents the CTb deposit in this animal. Scale bar, $3 \mathrm{~mm} . b c$, Brachium conjunctivum; $b p$, brachium pontis; $i C$, inferior colliculus; $i O$, inferior olive; $K F$, Kolliker-Fuse nucleus; $\mathrm{MeV}$, mesencephalic trigeminal nucleus; $m V$, trigeminal motor nucleus; $m V I I$, facial nucleus; $m X I I$, hypoglossal nucleus; $p$, pyramid; $P$, posterior; $P A G$, periaqueductal gray; $p V$, sensory principal trigeminal nucleus; $r O$, raphe obscurus; $s V$, spinal trigeminal complex; $V$, trigeminal tract.

neurons. In terms of stereotaxic coordinates (Berman, 1968), the structures occupied by these cells are bounded by posterior $8.2-$ 9.4, lateral $0.0-3.0$, and vertical 6.5-8.5. These neurons were therefore located within the $\mathrm{Mc}$ and the ventral aspects of the NRGc. These neurons were more often present in clusters in the lateral portions of the $\mathrm{Mc}$, usually intermingled with $\mathrm{CTb}^{+}, \mathrm{Fos}^{-}$ cells and with $\mathrm{CTb}^{-}$, Fos ${ }^{+}$neurons (Fig. 7). In those cats in which the $\mathrm{CTb}$ injection site did not include the $\mathrm{mV}$ (two animals in which it was dorsal to the nucleus and one in which the injection was more posterior), the ventral medullary reticular formation did not contain neurons with the retrograde tracer.

CTb-labeled neurons exhibited a variety of cell bodies: multipolar, triangular, circular, oval, or elongated. Their mean soma

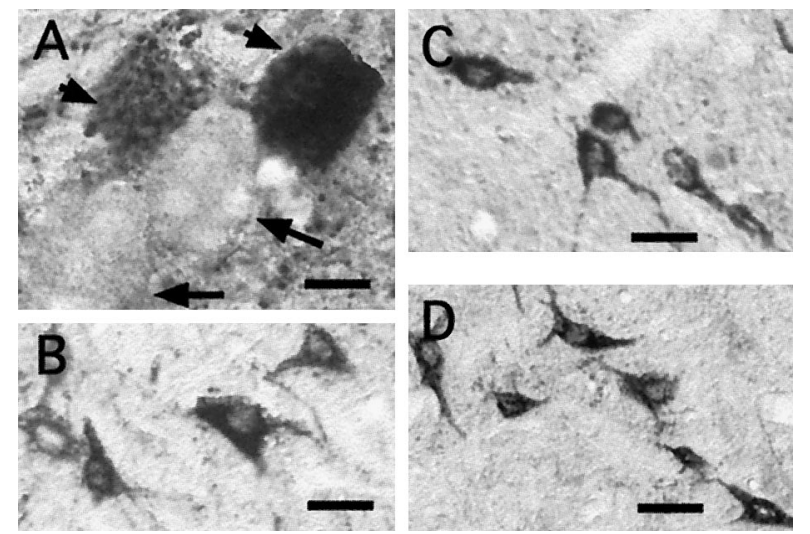

Figure 4. Lack of $c$-fos expression in sensory and premotor interneurons. $A$, A cluster of neurons of the $\mathrm{MeV}$ is shown. Two heavily $\mathrm{CTb}$-stained cells are indicated by the short arrows; in close apposition are two unstained neurons that are indicated by long arrows. $B$, Neurons of the spinal complex of the trigeminal nerve are represented. $C, D$, Interneurons of the supratrigeminal and commissural groups, respectively, are represented. All of these cells were $\mathrm{CTb}^{+}, \mathrm{Fos}^{-}$neurons. Scale bars, $50 \mu \mathrm{m}$.

diameter was $24.0 \pm 0.82 \mu \mathrm{m}$ ( \pm SEM) (10-90\% values were 18 and $32 \mu \mathrm{m}$, respectively). The multipolar or triangular neurons were generally larger than the oval or elongated cells. An example of a multipolar CTb-labeled neuron is illustrated in the photomicrograph in Figure $6 \mathrm{~A}$.

A large percentage $(55 \%)$ of $\mathrm{CTb}^{+}$neurons expressed $c$-fos after c-AS in experimental animals $(n=4)$. In contrast, in control cats $(n=2)$ only $7 \%$ of CTb-labeled cells expressed $c$-fos $(p<$ 0.001). In Figure 8 are two photomicrographs obtained from comparable medullary levels from an experimental and from a control cat illustrating $\mathrm{Ctb}^{+}$neurons. The bars charts in this figure illustrate the average number of $\mathrm{CTb}^{+}, \mathrm{Fos}^{-}$cells (empty bar) and the corresponding number of $\mathrm{CTb}^{+}, \mathrm{Fos}^{+}$cells ( filled bar) counted in five sections of the ventromedulla in four experimental and two control cats, respectively.

Immunostaining for protein-conjugated glycine in combination with either CTb or Fos (see Materials and Methods) indicated that many $\mathrm{Fos}^{+}$ventromedullary cells are glycinergic and that, in addition, many glycinergic cells are indeed pretrigeminal interneurons. Examples of these neurons are illustrated in Figure 9. Because during the course of this work we have found many premotor neurons with diverse neurotransmitter phenotype (see also Holstege, 1996), we consider that the quantification of the data and the issue of the nature of other c-fos-expressing cells must await the termination of a comprehensive immunocytological study.

\section{c-fos expression in the nucleus paramedianus}

We did not find CTb-labeled cells within this structure. However, this nucleus exhibited a greater number of $\mathrm{Fos}^{+}$neurons after AS compared with control animals $(12 \pm 0.9$ and $3 \pm 0.5$, respectively; $p<0.0001$ per section, respectively). There was a tendency for neurons that express $c$-fos to be located in the ventral portions of this nucleus immediately dorsal to the inferior olive.

\section{DISCUSSION}

In the present study we describe a population of premotor interneurons that, according to their pattern of $c$-fos expression, are activated during c-AS. The inhibitory postsynaptic processes that take place in somatic motoneurons during this pharmacologically 

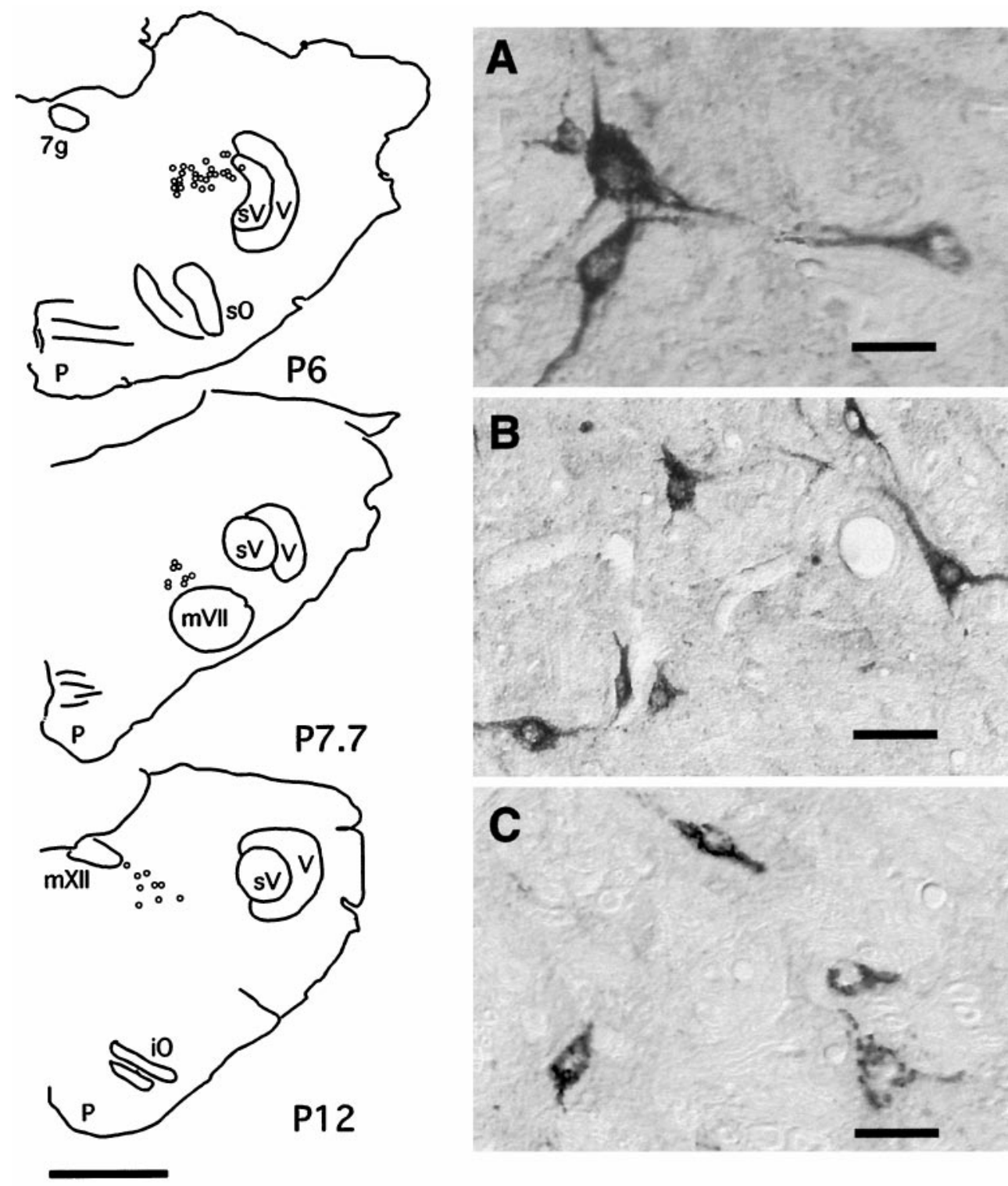

Figure 5. Distribution of $\mathrm{CTb}^{+}$, Fos trigeminal interneurons in the parvocellular reticular formation (PCRf). Left, The diagrams are of coronal sections of the brainstem of an experimental cat at three different brainstem levels. At P6, medial to the spinal sensory nucleus of the trigeminal complex, the PCRf corresponds to the rat parvocellularis $\alpha$. Note that none of the PCRf premotor neurons expressed $c$-fos during c-AS. A-C (right), In the photomicrographs are examples of $\mathrm{CTb}^{+}, \mathrm{Fos}^{-}$neurons located in histological sections from the three levels represented in the diagrams. Scale bars: $A-C, 50 \mu \mathrm{m}$; diagram on left, $3 \mathrm{~mm}$. $i O$, Inferior olive; $m V I I$, facial nucleus; $m X I I$, hypoglossal nucleus; $p$, pyramid; $P$, posterior; $s O$, superior olive; $s V$, spinal trigeminal complex; $V$, trigeminal tract; $7 g$, genus of the facial nerve. induced state are indistinguishable from those occurring during normal AS (Morales et al., 1987b; López-Rodríguez et al., 1995; Kohlmeier et al., 1996; Xi et al., 1997a,b). Therefore, it is likely that the responsible premotor inhibitory cells are activated during c-AS; the data in the present work are interpreted based on this assumption. Premotor, $\mathrm{Fos}^{+}$neurons were found within the $\mathrm{Mc}$ and the ventral portion of the NRGc and therefore populate the rostral portion of the medullary area known as the "inhibitory region of Magoun and Rhines" (Magoun and Rhines, 1946; see also Jankowska et al., 1968).

\section{The subdivisions of the medullary reticular formation populated by $\mathrm{CTb}^{+}$, Fos ${ }^{-}$-labeled neurons}

The parvocellularis reticular formation contained most of the reticular interneurons that innervate the trigeminal motor pool, confirming results obtained in feline and rodents (Mizuno et al., 1983; Travers and Norgren, 1983; Fort et al., 1990; Ter Horst et al., 1991; Turman and Chandler, 1994; Rampon et al., 1996b). The possibility that the parvocellularis reticular formation contains premotor cells that inhibit trigeminal motoneurons during AS has been proposed previously (Castillo et al., 1991; Rampon et al., 1996b). Recently, Rampon et al. (1996b) hypothesized that the subdivision $\alpha$ of the parvocellular reticular formation is the source of trigeminal inhibition during AS. Their arguments were based on their determination that this region is the principal source of the glycinergic innervation of the $\mathrm{mV}$.

The parahypoglossal parvocellular reticular formation was also regarded as a source of postsynaptic inhibition during AS. For example, low-intensity stimulation (as low as $10 \mu \mathrm{A}$ ) of this region evoked nonreciprocal, bilateral, monosynaptic glycinergic inhibition in both jaw closer and opener motoneurons (Pedroarena et al., 1990; Castillo et al., 1991). There is now evidence of the existence of inhibitory and excitatory premotor masseter interneurons in this region that discharge rhythmically during mastication (Nozaki et al., 1993). Therefore, the parvocellular reticular formation probably contains networks that have integrative functions in jaw movements and posture (see also Mogoseanu et al., 1993).

The data obtained in the present work make the possibility that parvocellular reticular formation premotor interneurons participate in the generation of the atonia of AS doubtful. In effect, we 


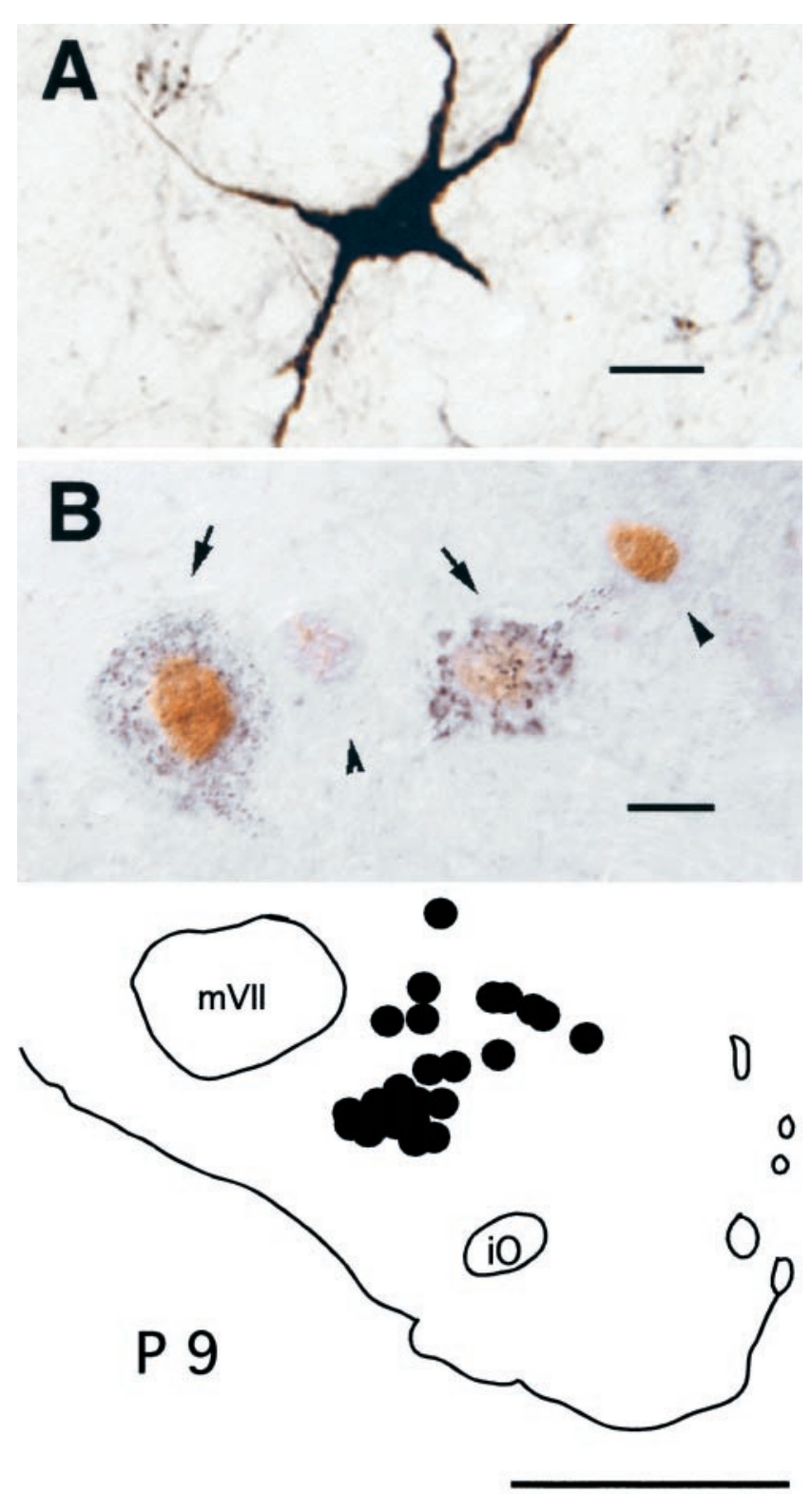

Figure 6. Fos $^{+}$neurons in the ventromedullary reticular formation. $A, \mathrm{~A}$ photomicrograph of a heavily $\mathrm{CTb}$-stained premotor neuron located in the magnocellularis nucleus of an experimental cat is shown. B, A photomicrograph of a cluster of $\mathrm{Fos}^{+}$neurons located in the same structure in another animal is shown. The arrows indicate neurons that contain intracytoplasmic granules of retrogradely transported $\mathrm{CTb}$. The nuclei of these cells were immunoreactive for the Fos protein. The arrowheads point to two neurons of the cluster that do not contain the retrograde label but whose nuclei express $c$-fos. Bottom, The diagram illustrates the location of double-labeled $\mathrm{Ctb}^{+}, \mathrm{Fos}^{+}$neurons within the ventromedial medulla, ipsilateral to the injection site (filled circles). This diagram was drawn from four superimposed sections. Scale bars: $A, 20$ $\mu \mathrm{m} ; B, 10 \mu \mathrm{m}$. $i O$, Inferior olive; $m V I I$, facial nucleus; $P$, posterior.

did not observe parvocellularis premotor cells expressing $c$-fos during c-AS, whereas a considerable population of premotor interneurons of the ventromedullary reticular formation expressed this immediate early gene. Nevertheless, the results obtained using $c$-fos immunocytochemical methods must be critically evaluated because there are cases in which neurons that discharge action potentials are not labeled by the Fos antibody [false negatives (Dragunow and Faull, 1989; Yamuy et al., 1993;

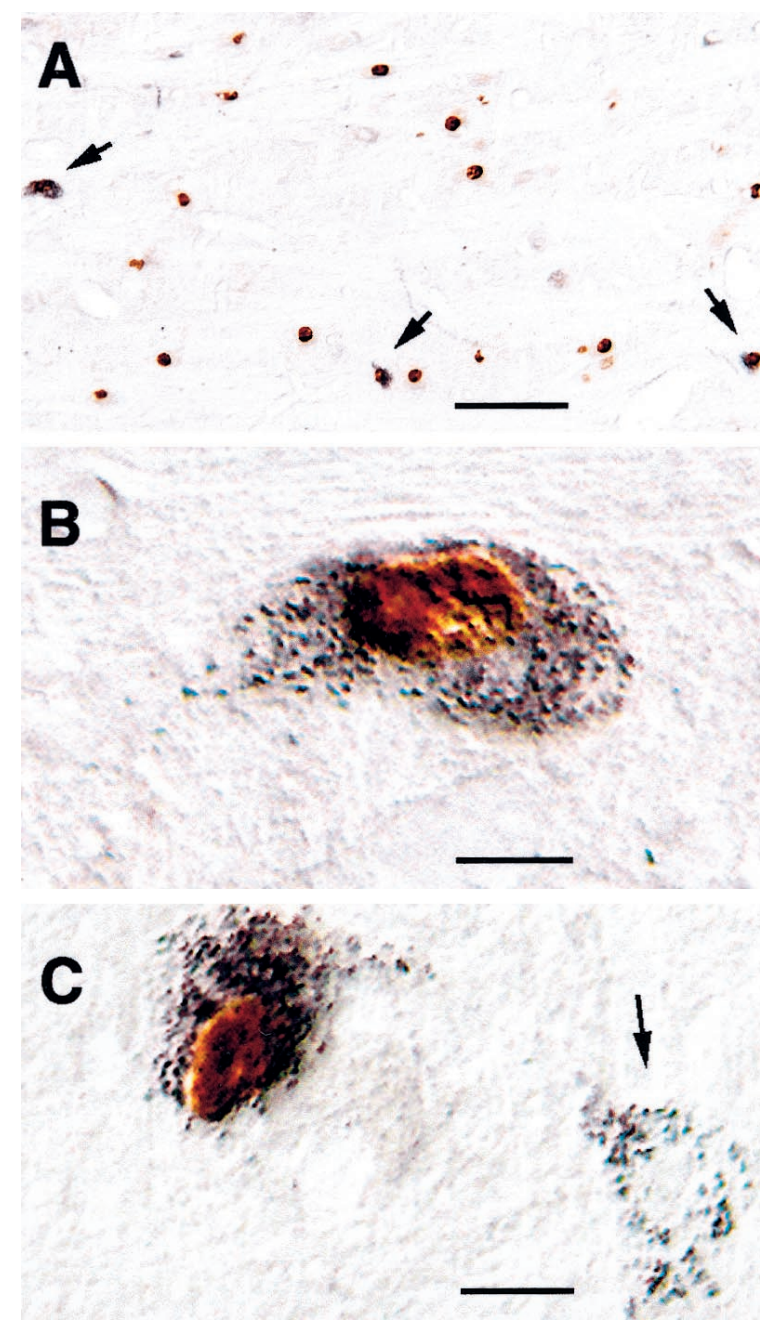

Figure 7. Fos $^{+}$neurons in the magnocellular reticular formation. $A, B$, The photomicrograph in $A$ was taken at low magnification $(10 \times)$ to illustrate the concentration of $\mathrm{Fos}^{+}$nuclei in this region. The arrows point to three double-labeled $\mathrm{CTb}^{+}, \mathrm{Fos}^{+}$neurons in this section; the neuron on the left is shown at a higher magnification $(40 \times)$ in the photomicrograph in $B$. $C$, In this photomicrograph there are two CTb-retrogradely labeled magnocellular neurons. The arrow points to one premotor cell that did not express $c$-fos during c-AS.

Herrera and Robertson, 1996; Chaudhuri, 1997)]. In addition, as pointed out by Maloney et al. (1999) c-fos may be expressed independently of neuronal discharge as a consequence of intracellular metabolic changes (see also Dragunow and Faull, 1989; Herrera and Robertson, 1996; Chaudhuri, 1997).

Glycinergic pretrigeminal interneurons are also located in both the $\mathrm{SuV}$ and the IntV nuclei (Turman and Chandler, 1994; Rampon et al., 1996b). A wealth of evidence indicates that neurons in these structures participate in jaw movements, posture, and reflexes (Luschei and Goldberg, 1981; Lund and Olsson, 1983; Turman and Chandler, 1994; Minkels et al., 1995).

\section{The reticular formation subdivisions populated by double-labeled, CTb ${ }^{+}$, Fos ${ }^{+}$neurons}

In the medial medullary reticular formation there were an estimated $700 \mathrm{CTb}^{+}$-labeled neurons, $90 \%$ of them ipsilateral to the $\mathrm{CTb}$ injection site. Fifty five percent of these neurons expressed $c$-fos during c-AS. These neurons tended to cluster in lateral regions of the ventromedial medullary reticular formation, al- 

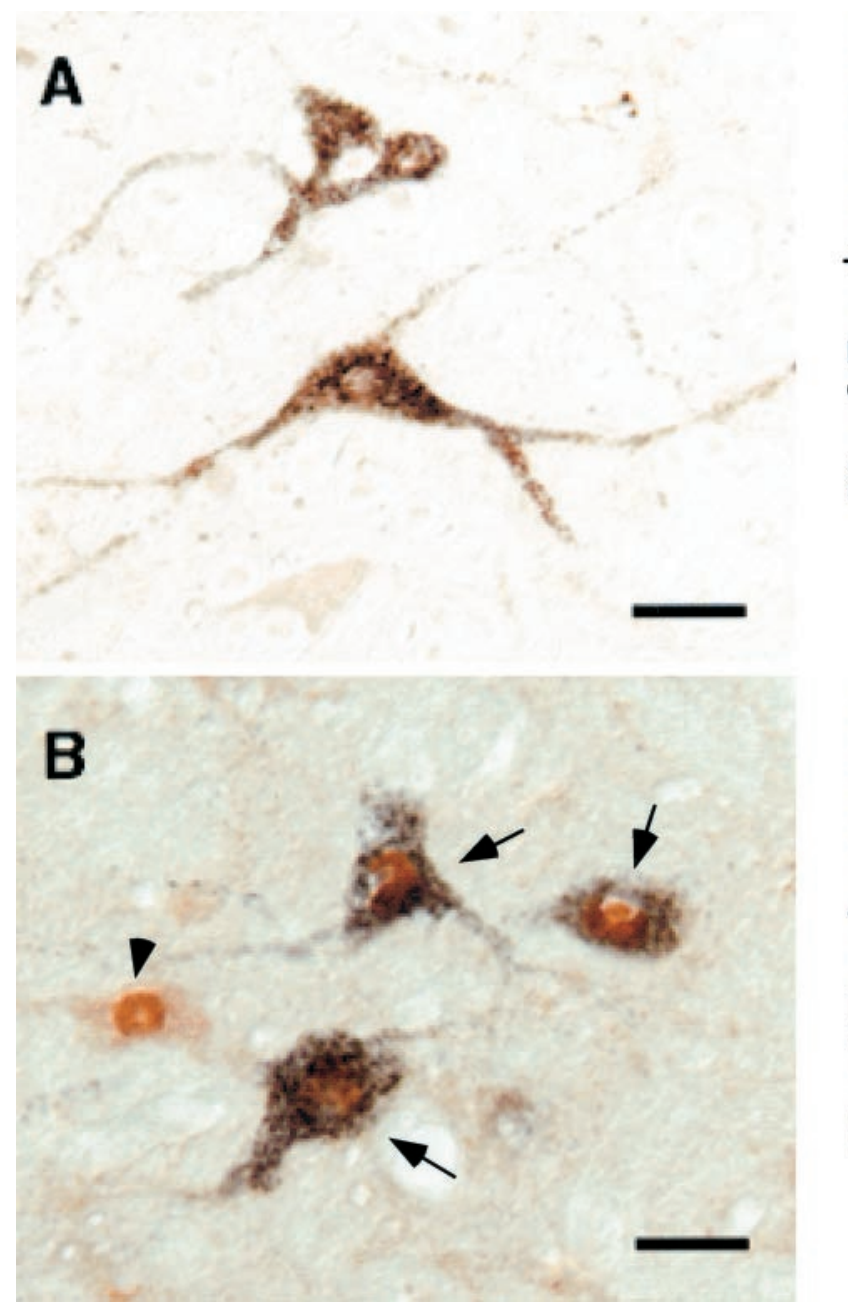

though scattered double-labeled cells were also found in the medial aspect of the medullary reticular formation. It is likely that these neurons, or a subpopulation, are responsible for trigeminal motoneuron inhibition during AS. Evidence from previous experiments supports this hypothesis. Electrical stimulation of this region suggested the existence of a direct, monosynaptic inhibitory projection from this region to masseter motoneurons (Nakamura et al., 1975). In addition, Chase et al. (1984) recorded units in this region that showed their highest frequency of discharge during AS and elicited monosynaptic IPSPs in the masseter pool as determined by field potential analysis using spike-triggered averaging techniques.

The ventromedial medulla contains neurons of diverse neurotransmitter phenotypes that are involved in a variety of functions (for review, see Holstege, 1996). Among these, there are inhibitory neurons that project to other motor nuclei of the brainstem and the spinal cord. With respect to brainstem nuclei, anatomical studies in the rat have demonstrated the existence, in this region, of glycinergic neurons that project to facial and hypoglossal nuclei as well as to trigeminal motor pools (Fort et al., 1990; Li et al., 1996, 1997). A direct neuronal projection from the Mc to hindlimb motoneurons has been demonstrated by Taal and Holstege (1994). According to these authors, a considerable portion of the synaptic terminals from these projections have glycine and GABA colocalized. In turn, Yang et al. (1997) have also found mixed glycine-GABAergic synapses impinging on trigeminal
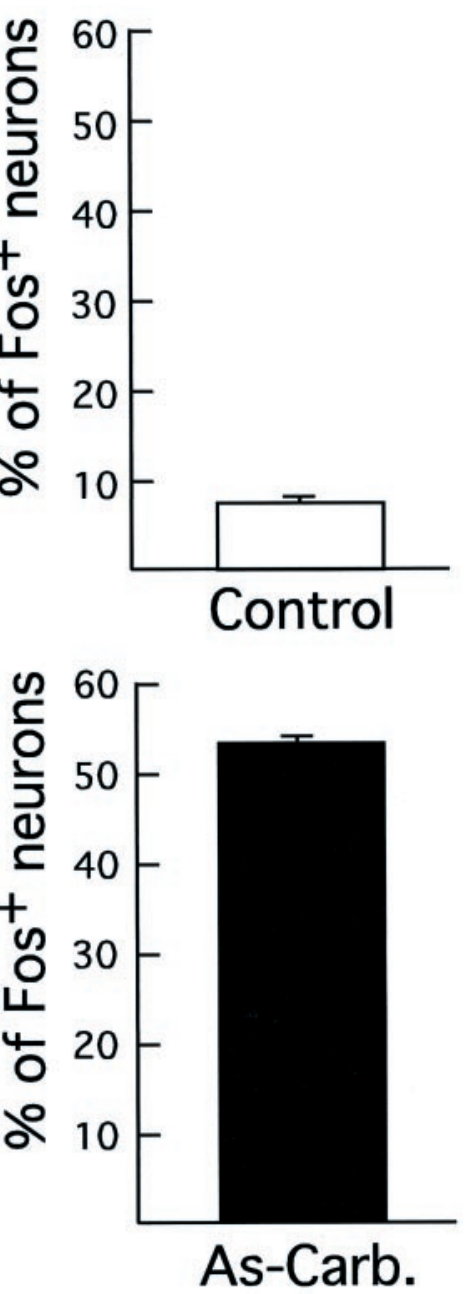

Figure 8. c-fos expression in premotor medullary interneurons in control $(A)$ and experimental $(B)$ cats. The sections illustrated were processed for both $\mathrm{CTb}$ and Fos protein immunostaining. $A$ (left), The photomicrograph illustrates three $\mathrm{CT}$ b-labeled neurons in the ventromedulla of a control cat. These cells did not express $c$-fos. $B$ (left), In the photomicrograph is a cluster of $\mathrm{Fos}^{+}$neurons in the ventromedial medulla of an experimental cat. Three of these neurons (indicated by arrows) contained $\mathrm{CTb}$ and likely innervate the trigeminal motor nuclei. Another neuron of the cluster (indicated by the left arrowhead) did not contain the CTb label. Right, The bar charts represent the number of $\mathrm{CTb}^{+}, \mathrm{Fos}^{+}$neurons expressed as percentages of the total number of $\mathrm{CTb}^{+}$neurons within the ventromedial medulla. These data were obtained from two control and four experimental cats. Mean control: $7.5 \pm$ $0.7 \%$ ( \pm SEM); mean carbacholinduced active sleep (As-Carb.): $52 \pm$ $1.2 \% ; p<0.0001$. Scale bars, $25 \mu \mathrm{m}$. motoneurons, but their source has not yet been determined. In pharmacological experiments designed to identify the neurotransmitter that mediates the AS-specific IPSPs (Morales et al., 1987a), we have shown that although these IPSPs were completely blocked by strychnine, a glycinergic antagonist, they were shortened by GABA-A blockers, as though there was some (although small) GABAergic component in the AS postsynaptic inhibition of motoneurons (Chase et al., 1989).

Electrical stimulation of the ventral medulla results in inhibition of spinal and trigeminal motoneurons (Magoun and Rhines, 1946; Jankowska et al., 1968; Nakamura et al., 1975). Glutamatergic stimulation suppresses the tone of the cervical musculature in the decerebrate cat, an effect that is viewed by the authors (Lai and Siegel, 1988, 1990) as reflecting the process by which the atonia of AS is generated. Extracellular recordings from NRGc and Mc neurons demonstrate units that discharge specifically during AS (Kanamori et al., 1980; Chase et al., 1984; Sakai, 1988). In narcoleptic dogs specific discharge of Mc units has been described during cataplectic attacks (Siegel et al., 1991). Therefore these data, taken together, indicate that the ventromedial medulla contains interneurons that are the source of motoneuron inhibition under both physiological (active sleep) and pathological (narcolepsy) conditions.

In the present report we have demonstrated a direct, probably inhibitory, projection to the $\mathrm{mV}$ that appears to be activated during AS. However, similar data are not available for spinal cord 


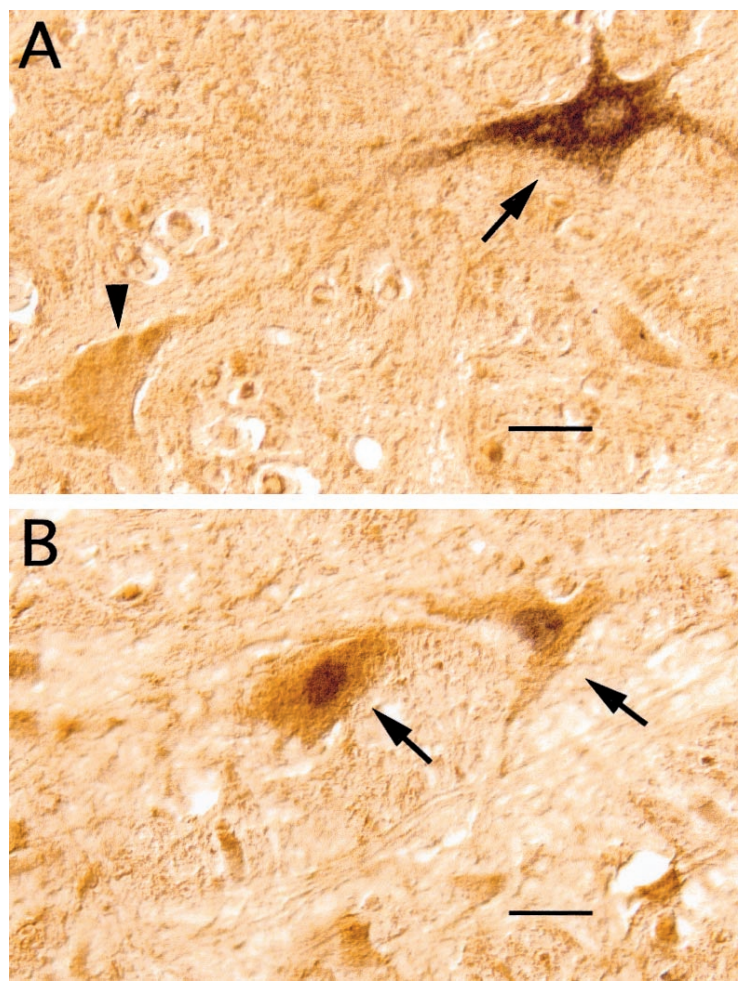

Figure 9. Glycine-like immunoreactive neurons in the ventromedial medullary reticular formation of an experimental cat that was injected with $\mathrm{CTb}$ in the trigeminal motor nucleus. $A$, The histological section in the photomicrograph was processed for both glycine and CTb immunostaining. Two neurons of the magnocellular reticular formation that stained positive to an antibody raised against glycine-conjugated protein may be observed in this photomicrograph. The cell indicated by the arrowhead exhibits glycine-like immunoreactivity but does not contain $\mathrm{CTb}$. Instead, the cell indicated by the arrow on the right exhibits both glycine-like immunoreactivity and $\mathrm{CTb}$ retrogradely transported from the $\mathrm{mV}$ deposit. $B$, The histological section in the photomicrograph was processed for both glycine and Fos immunostaining. Neurons illustrated in $B$ (arrows), positive to the glycine antibody, express $c$-fos during carbachol-induced active sleep. Scale bars, $15 \mu \mathrm{m}$.

motor pools. In fact, the possibility that the spinal motoneurons are inhibited during AS via segmental inhibitory interneurons that are activated, in turn, by an excitatory projection from the medulla still needs to be considered (Mori, 1987; Takakusaki et al., 1989) [We, in fact, have examined this possibility before (Morales et al., 1988; Xi et al., 1997) and concluded that neither Renshaw cells, Ia, nor the subtype of Ib interneurons that innervate Clarke neurons are likely to mediate this inhibition.] It is, in this regard, conceivable that $\mathrm{Fos}^{+}$neurons consist of a heterogenous population of cells with respect to their neurotransmitter phenotype and that some could function as excitatory neurons. Moreover, the Mc reticulospinal projections that mediate spinal motoneuron inhibition appear to be more complex that originally thought (Pompeiano, 1967). For example, Kohyama et al. (1998) recently described two sets of reticulospinal units that had different conduction velocities and different patterns of activation from the pons. According to these authors, these results indicate the existence of two systems that mediate the atonia of AS. It is possible that one set of reticulospinal units excites spinal inhibitory interneurons and the other directly inhibits spinal motoneurons, although Kohyama et al. (1998) did not consider this possibility.
Glutamatergic synaptic transmission seems to underlie the activation of the Mc neurons that are responsible for the suppression of decerebrate rigidity in the cat (Lai and Siegel, 1988; Kodama et al., 1998). Cholinergic, but not glutamatergic, agonists administered within the nPR evoke a similar response. These observations suggest that there is a dichotomy in the process of motor suppression during AS, with two regions involved, one cholinoceptive and the other sensitive to glutamate. The data described in the present work (see also Yamuy et al., 1993) support a role for the $\mathrm{nPR}$ after AS because a greater number of $\mathrm{Fos}^{+}$neurons was found in this structure during c-AS than in control animals. However, our data do not provide information regarding the neurotransmitter phenotype of the activated neurons within this nucleus and/or of the type of synaptic innervation that these neurons receive, which would be needed to elucidate the function(s) of the nPR nucleus during AS.

\section{CONCLUSION}

The present report describes, at a cellular level of anatomical analysis, premotor interneurons that are located in the ventromedial medullary reticular formation and are likely responsible for motor inhibition during active sleep.

\section{REFERENCES}

Baghdoyan HA, Rodrigo-Angulo ML, McCarley RW, Hobson JA (1987) A neuroanatomical gradient in the pontine tegmentum for the cholinoceptive induction of desynchronized sleep signs. Brain Res 414:245-261.

Berman AL (1968) The brainstem of the cat. A cytoarchitectonic atlas with stereotaxic coordinates. Madison, W I: University of Wisconsin.

Castillo P, Pedroarena C, Chase M, Morales FR (1991) A medullary inhibitory region for trigeminal motoneurons in the cat. Brain Res 549:346-349.

Chandler SH, Nakamura Y, Chase MH (1980) Intracellular analysis of synaptic mechanism controlling trigeminal motoneuron activity during sleep and wakefulness. J Neurophysiol 44:359-371.

Chase M, Enomoto S, Hiraba K, Katoh M, Nakamura Y, Sahara Y, Tiara M (1984) Role of medullary reticular neurons in the inhibition of trigeminal motoneurons during active sleep. Exp Neurol 84:364-373.

Chase MH, Soja PJ, Morales FR (1989) Evidence that glycine mediates the postsynaptic potentials that inhibit lumbar motoneurons during the atonia of active sleep. J Neurosci 9:743-751.

Chaudhuri A (1997) Neural activity mapping with inducible transcription factors [minireview]. NeuroReport 8:iii-vii.

Coggeshall RE (1992) A consideration of neural counting methods. Trends Neurosci 15:9-13.

Coggeshall RE, Lekan HA (1996) Methods for determining numbers of cells and synapses: a case for more uniform standards of review. J Comp Neurol 364:6-15.

Dement WC (1958) The occurrence of low voltage fast electroencephalogram patterns during behavioral sleep in the cat. EEG Clin Neurophysiol 10:29.

Dragunow M, Faull R (1989) The use of $c$-fos as a metabolic marker in neuronal pathway tracing. J Neurosci Methods 29:261-265.

Fort P, Luppi PH, Sakai K, Salvert D, Jouvet M (1990) Nuclei of origin of monoaminergic, peptidergic, and cholinergic afferents to the cat trigeminal motor nucleus: a double-labeling study with cholera-toxin as a retrograde tracer. J Comp Neurol 301:262-275.

Fung SJ, Yamuy J, Xi MC, Morales FR, Chase MH (1998) Postsynaptic inhibition of hypoglossal motoneurons during carbachol-induced motor suppression in a-chloralose anesthetized cats. Soc Neurosci Abstr 24:1695.

Glenn LL, Dement WC (1981) Membrane resistance and rheobase of hindlimb motoneurons during wakefulness and sleep. J Neurophysiol 46:1076-1088.

Herrera DG, Robertson HA (1996) Activation of $c$-fos in the brain. Prog Neurobiol 50:83-107.

Holstege JC (1996) The ventro-medial medullary projections to spinal motoneurons: ultrastructure, transmitters and functional aspects. Prog Brain Res 107:159-181.

Jankowska E, Lund S, Lundberg A, Pompeiano O (1968) Inhibitory 
effects evoked through ventral reticulospinal pathways. Arch Ital Biol 106:124-140.

Jones BE (1991) Paradoxical sleep and its chemical/structural substrates in the brain. Neuroscience 40:637-656.

Jouvet M, Michel F, Courjon J (1959) Sur un etade d'activité électrique cérébrale rapide au cours du sommeil physiologique. CR Soc Biol 153:1024-1028.

Kanamori N, Sakai K, Jouvet M (1980) Neuronal activity specific to paradoxical sleep in the ventromedial medullary reticular formation of unrestrained cats. Brain Res 189:251-255.

Kidokoro Y, Kubota K, Shuto S, Sumino R (1968) Reflex organization of cat masticatory muscles. J Neurophysiol 31:695-708.

Kodama J, Lai YY, Siegel JM (1998) Enhanced glutamate release during REM sleep in the rostromedial medulla as measured by in vivo microdialysis. Brain Res 780:178-181.

Kohlmeier KA, López-Rodríguez F, Liu RH, Morales FR, Chase MH (1996) State dependent phenomena in cat masseter motoneurons. Brain Res 722:30-38.

Kohyama J, Lai YY, Siegel JM (1998) Reticulospinal systems mediate atonia with short and long latencies. J Neurophysiol 80:1839-1851.

Lai YY, Siegel JM (1988) Medullary regions mediating atonia. J Neurosci 8:4790-4796.

Lai YY, Siegel JM (1990) Cardiovascular and muscle tone changes produced by microinjection of cholinergic and glutamatergic agonists in dorsolateral pons and medial medulla. Brain Res 514:27-36.

Landgren S, Olsson KÁ, Wetberg KG (1986) Bulbar neurons with axonal projections to the trigeminal motor nucleus in the cat. Exp Brain Res 65:98-111.

Li Y-Q, Takada M, Kaneko T, Mizuno N (1996) GABAergic and glycinergic neurons projecting to the trigeminal motor nucleus: a double labeling study in the rat. J Comp Neurol 373:498-510.

Li Y-Q, Takada M, Kaneko T, Mizuno N (1997) Distribution of GABAergic and glycinergic premotor neurons projecting to the facial and hypoglossal nuclei in the rat. J Comp Neurol 378:283-294.

Liem RSB, Copray JCVM, Willigen JD (1991) Ultrastructure of the rat mesencephalic trigeminal nucleus. Acta Anat (Basel) 140:112-119.

López-Rodríguez F, Kohlmeier K, Morales FR, Chase MH (1994) State dependency of the effects of microinjection of cholinergic drugs into the nucleus pontis oralis. Brain Res 649:271-281.

López-Rodríguez F, Kohlmeier K, Yamuy J, Morales FR, Chase MH (1995) Muscle atonia can be induced by carbachol injections into the nucleus pontis oralis in cats anesthetized with a-chloralose. Brain Res 699:201-207.

Lorente de Nó R (1922) Contribución al conocimiento del nervio trigémino. In: Libro en honor de don Santiago Ramón y Cajal, Vol VII, pp-13-30. Madrid: Jaminez y Molina.

Luckman SM, Dyball RE, Leng G (1994) Induction of $c$-fos expression in hypothalamic magnocellular neurons requires synaptic activation and not simply increased spike activity. J Neurosci 14:4825-4830.

Lund JP, Olsson KA (1983) The importance of reflexes and their control during jaw movements. Trends Neurosci 6:458-463.

Luschei ES, Goldberg LJ (1981) Neural mechanisms of mandibular control: mastication and voluntary biting. In: Handbook of physiology. The nervous system, Vol II, Pt 2, pp 1237-1274. Bethesda, MD: Am Physiol Soc.

Magoun HW, Rhines R (1946) An inhibitory mechanism in the bulbar reticular formation. J Neurophysiol 9:165-171.

Maloney KJ, Mainville L, Jones B (1999) Differential c-fos expression in cholinergic, monoaminergic and GABAergic cell groups of the pontomesencephalic tegmentum after paradoxical sleep deprivation and recovery. J Neurosci 19:3057-3072.

Menétrey D, Gannon A, Levine JD, Basbaum AI (1989) Expression of $c$-fos protein in interneurons and projection neurons of the rat spinal cord in response to noxious somatic, articular, and visceral stimulation. J Comp Neurol 285:177-195.

Minkels RF, Jœch PJW, Willigen JD (1995) Interneurons of the supratrigeminal area mediating reflex inhibition of trigeminal and facial motoneurons in the rat. Arch Oral Biol 40:275-284.

Mizuno N, Nomura S, Itoh K, Nakamura Y, Konishi A (1978) Commisural interneurons for masticatory motoneurons: a light and electron microscopic study using the horseradish peroxidase tracer technique. Exp Neurol 59:254-262.

Mizuno N, Yasui Y, Nomura S, Itoh K, Konishi A, Takada M, Kudo M (1983) A light and electron microscopic study of the premotor neurons for the trigeminal motor nucleus. J Comp Neurol 215:290-298.
Mogoseanu D, Smith AS, Bolam JP (1993) Monosynaptic innervation of trigeminal motor neurons involved in mastication by neurons of the parvicellular reticular formation. J Comp Neurol 336:53-65.

Morales FR, Chase MH (1981) Postsynaptic control of lumbar motoneuron excitability during active sleep in the chronic cat. Brain Res 225:279-295.

Morales FR, Boxer P, Chase MH (1987a) Behavioral state-specific inhibitory postsynaptic potentials impinge on cat lumbar motoneurons during active sleep. Exp Neurol 98:418-435.

Morales FR, Engelhardt J, Soja PJ, Pereda AE, Chase MH (1987b) Motoneuron properties during motor inhibition produced by microinjection of carbachol into the pontine reticular formation of the decerebrated cat. J Neurophysiol 57:1118-1129.

Morales FR, Engelhardt J, Soja PJ, Pereda AE, Yamuy J, Chase MH (1988) Renshaw cells are inactive during motor inhibition produced by microinjection of carbachol into the pontine reticular formation of the decerebrated cat. Neurosci Lett 86:289-295.

Morales FR, Sampogna S, Yamuy J, Kohlmeier K, Chase M (1996) Premotor trigeminal interneurons activated during carbachol-induced active sleep. Soc Neurosci Abstr 22:690.

Mori S (1987) Integration of posture and locomotion in acute decerebrate and in awake, freely moving cats. Prog Neurobiol 28:161-195.

Nakamura Y, Takatori M, Nozaki S, Kikuchi M (1975) Monosynaptic reciprocal control of trigeminal motoneurons from the medial bulbar reticular formation. Brain Res 89:144-148.

Nozaki S, Iriki A, Nakamura Y (1993) Trigeminal premotor neurons in the bulbar parvocellular reticular formation participating in induction of rhythmical activity of trigeminal motoneurons by repetitive stimulation of the cerebral cortex in the guinea pig. J Neurophysiol 69:593-607.

Pompeiano O (1967) The neurophysiological mechanisms of the postural and motor events during desynchronized sleep. Res Publ Assoc Res Nerv Ment Dis 45:351-423.

Pedroarena C, Castillo P, Chase MH, Morales FR (1990) Nonreciprocal inhibition of digastric motoneurons. Brain Res 535:339-342.

Pedroarena C, Castillo P, Chase MH, Morales FR (1994) The control of jaw-opener motoneurons during active sleep. Brain Res 653:31-38.

Rampon C, Luppi PH, Fort P, Peyron C, Jouvet M (1996a) Distribution of glycine-immunoreactive cell bodies and fibers in the rat brain. Neuroscience 75:737-755.

Rampon C, Peyron C, Petit J-M, Fort P, Gervasoni D, Luppi P-H (1996b) Origin of the glycinergic innervation of the rat trigeminal motor nucleus. NeuroReport 7:3081-3085.

Sakai K (1988) Executive mechanisms of paradoxical sleep. Arch Ital Biol 126:239-257.

Saper CB (1996) Any way you cut it: a new journal policy for the use of unbiased counting methods. J Comp Neurol 364:5.

Siegel JM (1989) Brainstem mechanisms generating REM sleep. In: Principles and practice of sleep medicine (Kryger MH, Roth T, Dement WC, eds), pp 104-120. Philadelphia: Saunders.

Siegel JM, Nienhuis R, Fahringer HM, Paul R, Shiromani JP, Dement WC, Mignot E, Chiu C (1991) Neuronal activity in narcolepsy: identification of cataplexy-related cells in the medial medulla. Science 252:1315-1318.

Soja PJ, López-Rodríguez F, Morales FR, Chase MH (1991) The postsynaptic inhibitory control of lumbar motoneurons during the atonia of active sleep: effect of strychnine on motoneuron properties. J Neurosci $11: 2804-2811$.

Steriade M, McCarley RW (1990) Brainstem control of wakefulness and sleep (Steriade M, McCarley RE, eds). New York: Plenum..

Taal W, Holstege JC (1994) GABA and glycine frequently colocalize in terminals on cat spinal motoneurons. NeuroReport 5:2225-2228.

Taber E (1961) The cytoarchitecture of the brain stem of the cat. I. Brain stem nuclei of the cat. J Comp Neurol 116:27-69.

Takakusaki K, Ohta Y, Mori S (1989) Single medullary reticulospinal neurons exert postsynaptic inhibitory effects via inhibitory interneurons upon alpha-motoneurons innervating cat hindlimb muscles. Exp Brain Res 74:11-23.

Ter Horst GJ, Copray JCVM, Liem RSB, van Willigen JD (1991) Projections from the rostral parvocellular reticular formation to pontine and medullary nuclei in the rat: involvement in autonomic regulation and orofacial motor control. Neuroscience 40:753-758.

Tohyama M, Sakai K, Salvert D, Touret M, Jouvet M (1979) Spinal projections from the lower brainstem in the cat as demonstrated by the 
horseradish peroxidase technique. I. Origins of the reticulospinal tracts and their funicular trajectories. Brain Res 173:383-403.

Travers JB, Norgren R (1983) Afferent projections to the oral motor nuclei in the rat. J Comp Neurol 220:280-298.

Turman J, Chandler SH (1994) Immunohistochemical evidence for GABA and glycine-containing trigeminal premotoneurones in the guinea pig. Synapse 18:7-20.

Vanni-Mercier G, Sakai K, Lin JS, Jouvet M (1989) Mapping of cholinoceptive brainstem structures responsible for the generation of paradoxical sleep in the cat. Arch Ital Biol 127:133-164.

Xi MC, Liu RH, Yamuy J, Morales FR, Chase MH (1997a) Electrophysiological properties of lumbar motoneurons in the a-chloraloseanesthetized cat during carbachol-induced motor inhibition. J Neurophysiol 78:129-136.

Xi MC, Yamuy J, Liu RH, Morales FR, Chase MH (1997b) Dorsal spino-cerebellar tract neurons are not subjected to postsynaptic inhibition during carbachol-induced motor inhibition. J Neurophysiol 78:137-144.

Yamuy J, Mancillas JR, Morales FR, Chase MH (1993) c-fos expression in the pons and medulla of the cat during carbachol-induced active sleep. J Neurosci 13:2703-2718.

Yamuy J, Sampogna S, Morales FR, Chase MH (1998) c-fos expression in mesopontine noradrenergic and cholinergic neurons of the cat during carbachol-induced active sleep: a double labeling study. Sleep Res Online 1:28-40.

Yang HW, Min MY, Appenteng K, Batten TF (1997) Glycineimmunoreactive terminals in the rat trigeminal motor nucleus: lightand electron-microscopic analysis of their relationships with motoneurones and with GABA-immunoreactive terminals. Brain Res 749: 301-319. 